\title{
Effect of $5-\mathrm{HT}_{1 \mathrm{~B}}$ receptor agonists injected into the prefrontal cortex on maternal aggression in rats
}

\author{
C.P. Veiga ${ }^{1}$, \\ K.A. Miczek², \\ A.B. Lucion ${ }^{1}$ and \\ R.M.M. de Almeida ${ }^{3}$
}

\author{
1Programa de Pós-Graduação em Neurociências, \\ Universidade Federal do Rio Grande do Sul, Porto Alegre, RS, Brasil \\ ${ }^{2}$ Department of Psychology, Psychiatry, Pharmacology and Neuroscience, \\ Tufts University, Medford and Boston, MA, USA \\ ${ }^{3}$ Laboratório de Neurociências, Ciências da Saúde, \\ Universidade do Vale do Rio dos Sinos, UNISINOS, São Leopoldo, \\ RS, Brasil
}

\author{
Correspondence \\ R.M.M. de Almeida \\ Laboratório de Neurociências \\ Centro 2, UNISINOS \\ Av. Unisinos, 950 \\ 93022-000 São Leopoldo, RS \\ Brasil \\ E-mail: rmalmeida@unisinos.br \\ Some of these data were presented \\ at the XX Annual Meeting of the \\ Federação de Sociedades de \\ Biologia Experimental, \\ Águas de Lindóia, SP, Brazil, \\ August 24-27, 2005. \\ Research supported by Universidade \\ do Vale do Rio dos Sinos and \\ Universidade Federal do Rio Grande \\ do Sul, RS, Brazil. C.P. Veiga was \\ the recipient of a fellowship from \\ CAPES.
}

Received June 1, 2006 Accepted March 26, 2007

\begin{abstract}
Serotonin $\left(5-\mathrm{HT}_{1 \mathrm{~B}}\right)$ receptors play an essential role in the inhibition of aggressive behavior in rodents. CP-94,253, a 5- $\mathrm{HT}_{1 \mathrm{~B}}$ receptor agonist, can reduce aggression in male mice when administered directly into the ventro-orbitofrontal (VO) prefrontal cortex (PFC). The objective of the current study was to assess the effects of two selective $5-\mathrm{HT}_{1 \mathrm{~B}}$ receptor agonists (CP-94,253 and CP-93,129), microinjected into the VO PFC, on maternal aggressive behavior after social instigation in rats. CP-94,253 (0.56 $\mu \mathrm{g} / 0.2 \mu \mathrm{L}, \mathrm{N}=8$, and $1.0 \mu \mathrm{g} / 0.2 \mu \mathrm{L}, \mathrm{N}=8)$ or CP-93,129 (1.0 $\mu \mathrm{g} / 0.2 \mu \mathrm{L}, \mathrm{N}=9)$ was microinjected into the VO PFC of Wistar rats on the 9th day postpartum and 15 min thereafter the aggressive behavior by the resident female against a male intruder was recorded for $10 \mathrm{~min}$. The frequency and duration of aggressive and non-aggressive behaviors were analyzed using ANOVA and post hoc tests. CP-93,129 significantly decreased maternal aggression. The frequency of lateral attacks, bites and pinnings was reduced compared to control, while the non-aggressive behaviors and maternal care were largely unaffected by this treatment. CP-94,253 had no significant effects on aggressive or non-aggressive behaviors when microinjected into the same area of female rats. CP-93,129, a specific 5-HT receptor agonist, administered into the VO PFC reduced maternal aggressive behavior, while the CP-94,253 agonist did not significantly affect this behavior after social instigation in female rats. We conclude that only the $5-\mathrm{HT}_{1 \mathrm{~B}}$ receptor agonist $\mathrm{CP}-93,129$ administered into the VO PFC decreased aggression in female rats postpartum after social instigation.
\end{abstract}

Key words

- Prefrontal cortex

- 5-HT receptors

- Serotonin

- Maternal behavior

- Aggression

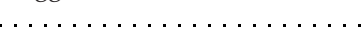


Activation of serotonin (5- $\left.\mathrm{HT}_{1 \mathrm{~B}}\right)$ receptors can play an inhibitory role in several types of aggressive behavior in rodents when injected intraperitoneally (1). CP-94,253, anpirtoline and zolmitriptan, all 5- $\mathrm{HT}_{1 \mathrm{~B}}$ receptor agonists, when administered systemically have anti-aggressive effects under conditions that induce moderate or escalated levels of aggression such as social instigation, self-administration of alcohol or frustration, without impairing non-aggressive activities (2,3). This 5-HT receptor subtype received considerable attention when mu$\operatorname{tant} 129 / \mathrm{Sv}$ mice lacking the gene for the 5$\mathrm{HT}_{1 \mathrm{~B}}$ receptor were found to display more aggressive behavior $(4,5)$. Among the most useful pharmacological tools employed to stimulate the $5-\mathrm{HT}_{1 \mathrm{~B}}$ receptors are the agonists CP-94,253 and CP-93,129 that have high affinity and selectivity for this receptor subtype $(\mathrm{CP}-94,253: \mathrm{Ki}=2.0 \pm 0.4 \mathrm{nM}$ and CP-93,129: $\mathrm{Ki}=8.1 \pm 1.6 \mathrm{nM})(6,7)$. CP93,129 is the agonist with the highest selectivity for $5-\mathrm{HT}_{1 \mathrm{~B}}$ relative to other 5-HT receptor subtypes, and is most effective when administered centrally due to its poor penetration of the blood-brain barrier (8). Autoradiographic and immunohistochemical studies have localized the 5- $\mathrm{HT}_{1 \mathrm{~B}}$ receptor in mesencephalic nuclei, basal ganglia and also in the cortex, including the ventro-orbitofrontal (VO) prefrontal cortex (PFC) (8-10). The PFC contains a considerable number of $5-\mathrm{HT}_{1 \mathrm{~B}}$ receptors (11) and is one of the most important sites for the anti-aggressive effects of the $5-\mathrm{HT}_{1 \mathrm{~B}}$ receptor agonists $(12,13)$.

The current study focuses on the PFC, more specifically the $\mathrm{VO}$ area, because of its important role in the inhibitory control of behavior, and in particular in the inhibition of impulsive and aggressive behavior (1416). Stimulation of $5-\mathrm{HT}_{1 \mathrm{~B}}$ receptors in the VO PFC proved to effectively reduce aggressive behavior in resident male mice confronting an intruder without discernible side effects (12). From a clinical perspective, it is important to study animal aggression that escalates above the species-typical level (2, 3 ). One experimental approach used to escalate aggressive behavior is to provoke an animal by exposing it to a rival, and this procedure is often referred to as social instigation (17-19). Most individuals engage in aggressive behavior at twice the usual level after being instigated than without such provocation $(2,3)$. Nearly all evidence about $5-\mathrm{HT}_{1 \mathrm{~B}}$ receptors and escalated aggression has been obtained from experiments with males, and there is an urgent need to investigate this neurobiological mechanism in female aggression.

The objective of the current study was to assess the effects of two selective 5- $\mathrm{HT}_{1 \mathrm{~B}}$ receptor agonists (CP-94,253 and CP-93,129) microinjected into the VO PFC on maternal aggressive behavior in rats that were socially instigated.

Female Wistar rats $(\mathrm{N}=42)$, born and bred at Universidade do Vale do Rio dos Sinos (UNISINOS) 3-4 months old and weighing 250-350 g were maintained on a 12:12-h light:dark cycle, lights on at 4:00 am. After delivery, each litter was randomly culled to 8 pups. To test aggressive behavior, the experimental female rats confronted male Wistar rats $(\mathrm{N}=42)$, which served as stimulus intruders. Some of these males were used as opponents for the social instigation. On the 3rd postpartum day, females were selected for aggressiveness and only those displaying more than 2 bites against the intruder during a 10-min session were used as subjects. The social instigation procedure was implemented on the 5 th postpartum day. The social instigation consisted of placing a clear perforated glass cylinder $(28 \mathrm{~cm}$ long, $10 \mathrm{~cm}$ in diameter) containing an opponent male in the center of the female residents' home cage for $5 \mathrm{~min}$. The residents typically threatened the protected opponent and attacked the perforated glass cylinder. In general, rodents initiate attacks with very short latency and at high frequency when tested with an intruder in their home cage after 
having been provoked previously by an opponent (18). Social instigation specifically increases aggression and does not trigger other activities such as feeding, sexual behavior or locomotion $(18,19)$, presumably due to increased "aggressive arousal" or "attack readiness" $(17,18)$. During the social instigation and the behavioral test with the intruder the pups remained inside the cage together with their dams.

On the 6th day postpartum, each female was anesthetized with $100 \mathrm{mg} / \mathrm{kg}$ ketamine and $100 \mathrm{mg} / \mathrm{kg}$ xylazine intraperitoneally, placed in a stereotaxic frame (David Kopf, Tujunga, CA, USA), and implanted with a guide cannula (22 gauge) fixed with dental cement to the skull. The cannula was aimed at the VO PFC in the right hemisphere: 4.3 $\mathrm{mm}$ anterior to the bregma, $0.6 \mathrm{~mm}$ lateral to the sagittal line, and $2.1 \mathrm{~mm}$ below the dura mater. The parameters were based on the Paxinos and Watson Atlas for Rats. Experiments were performed in accordance with the NIH Guide for Animal Care and Use and were approved by the Research Committee of the University. Females remained separated from the pups for $2 \mathrm{~h}$.

On the 9th postpartum day, the microinjections were followed by the resident-intruder test. The naive male intruder was placed inside the female's cage and immediately thereafter the behaviors were videotaped for $10 \mathrm{~min}$. The behavioral recordings began $15 \mathrm{~min}$ after the injection of $\mathrm{CP}$ 93,129 , CP-94,253 or vehicle. The drugs used in this experiment were donated by Pfizer. CP-93,129, a 5-HT ${ }_{1 \mathrm{~B}}$ receptor agonist (Pfizer, Groton, CT, USA), was diluted in $0.9 \%$ saline and CP-94,253 (Pfizer) was diluted in $90 \%$ distilled water containing $5 \%$ dimethylsulfoxide and 5\% Tween 80. Each animal received only one injection per brain area of CP-93,129 (1.0 $\mu \mathrm{g}, \mathrm{N}=9)$ and vehicle $(\mathrm{N}=8)$ or $\mathrm{CP}-94,253(0.56$ or $1.0 \mu \mathrm{g}, \mathrm{N}$ $=8$ for each group $)$ or vehicle $(\mathrm{N}=8)$ and the injection volume was $0.2 \mu \mathrm{L}$. The solution was slowly infused using a Hamilton sy- ringe connected by tubing to the injecting needle, that was left in situ for 1 additional min after the microinjection.

After the completion of all behavioral tests, the dams were deeply anesthetized with an overdose of sodium thiopental. Brains were perfused with $0.9 \%$ saline followed by $10 \%$ formaldehyde. The brains were removed and fixed in $4 \%$ formaldehyde and later cut into $50-\mathrm{mm}$ coronal slices on a vibratome. The slices were placed on gelatinized slides and stained with cresyl violet. Locations of the cannula tips were determined by microscopy and only data from the animals with the correct location were used.

The frequency of each behavior is reported as mean \pm SEM. The effects of CP93,129 microinjections on the frequency of the behavioral measures were assessed using the Student $t$-test, and those of CP-94,253 by analysis of variance (ANOVA) followed by the post hoc Newman-Keuls test. In all cases, the alpha level was set at 0.05 .

As shown in Figure 1, microinjection of CP-93,129 (1.0 $\mu \mathrm{g} / 0.2 \mu \mathrm{L})$ significantly reduced the frequency of lateral attacks $(\mathrm{P}=$ 0.005), lateral threats $(\mathrm{P}=0.01)$ and pinnings $(\mathrm{P}=0.02)$ relative to saline control. In contrast to the decrease in all offensive behaviors (lateral attack, lateral threat and pinning) by the resident female rats, the concurrently assessed frequency of non-aggressive behaviors such as walking, grooming and pup care was unchanged after CP-93,129 microinjection (Table 1). The duration of sniffing decreased $(\mathrm{P}=0.03)$ after microinjection of CP-93,129, and the rearing behavior increased $(\mathrm{P}<0.05$; Table 1$)$.

Neither dose of CP-94,253 (0.56 or 1.0 $\mu \mathrm{g})$ altered the frequency of any salient aggressive behaviors (lateral attack $(\mathrm{F}(2.21)=$ $0.54 ; \mathrm{P}=0.5)$, lateral threat $(\mathrm{F}(2.21)=0.26$, $\mathrm{P}=0.7)$, pinning $(\mathrm{F}(2.21)=0.15 ; \mathrm{P}=0.8)$ (Figure 1). Furthermore, most of the nonaggressive behaviors (walking, grooming, pup care, sniffing, and rearing) were not affected by microinjections with CP-94,253 
(Table 1).

The lack of effect of CP-94,253 microinjections into the VO PFC, at the doses studied, on the aggressive behavior of lactating rats contrasts with the highly effective antiaggressive effects of 0.56 and $1.0 \mu \mathrm{g}$ of microinjections into the same brain region in aggressive resident male mice (12). Sys-

Table 1. Duration of non-aggressive behaviors after microinjection of CP-93,129 and CP-94,253.

\begin{tabular}{lccccc}
\hline $\begin{array}{l}\text { Non-aggressive } \\
\text { behavior }\end{array}$ & $\begin{array}{l}\text { Saline } \\
(\mathrm{N}=8)\end{array}$ & $\begin{array}{c}\mathrm{CP}-93,129 \\
(1.0 \mu \mathrm{g} ; \mathrm{N}=9)\end{array}$ & $\begin{array}{c}\text { Vehicle } \\
(\mathrm{N}=8)\end{array}$ & $\begin{array}{c}\mathrm{CP}-94,253 \\
(0.56 \mu \mathrm{g} ; \mathrm{N}=8)\end{array}$ & $\begin{array}{c}\mathrm{CP}-94,253 \\
(1.0 \mu \mathrm{N} ; \mathrm{N}=8)\end{array}$ \\
\hline Walking duration & $98.4 \pm 14.5$ & $91.6 \pm 12.3$ & $68.1 \pm 11.3$ & $100.3 \pm 17.7$ & $93.8 \pm 14.2$ \\
Grooming duration & $53.3 \pm 13.0$ & $37.2 \pm 10.8$ & $42.5 \pm 16.7$ & $39.3 \pm 7.5$ & $25.7 \pm 12.3$ \\
Pup care duration & $6.9 \pm 4.1$ & $16.3 \pm 10.6$ & $52.2 \pm 38.2$ & $10.0 \pm 10.0$ & $70.9 \pm 2.4$ \\
Sniffing duration & $170.4 \pm 30.7$ & $84.2 \pm 20.7^{*}$ & $147.2 \pm 21.0$ & $145.8 \pm 40.9$ & $158.5 \pm 36.0$ \\
Rearing duration & $11.5 \pm 5.5$ & $43.4 \pm 14.0^{*}$ & $18.9 \pm 6.2$ & $30.4 \pm 12.0$ & $12.1 \pm 4.5$
\end{tabular}

Data are reported as means \pm SEM in seconds.

${ }^{*} \mathrm{P}<0.05$ compared to control (Student $t$-test).
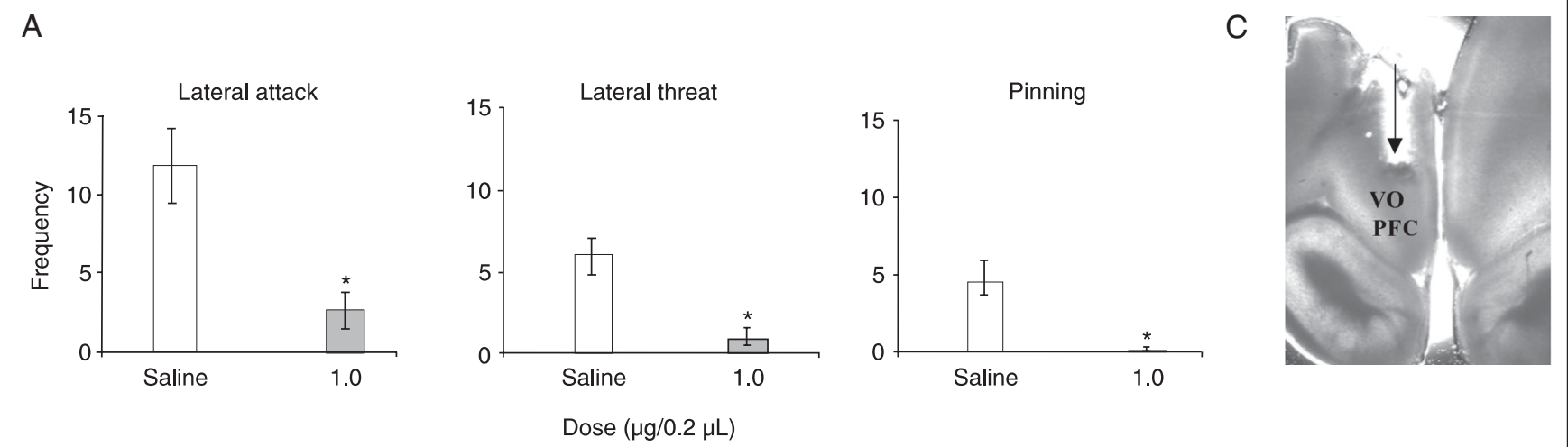

B
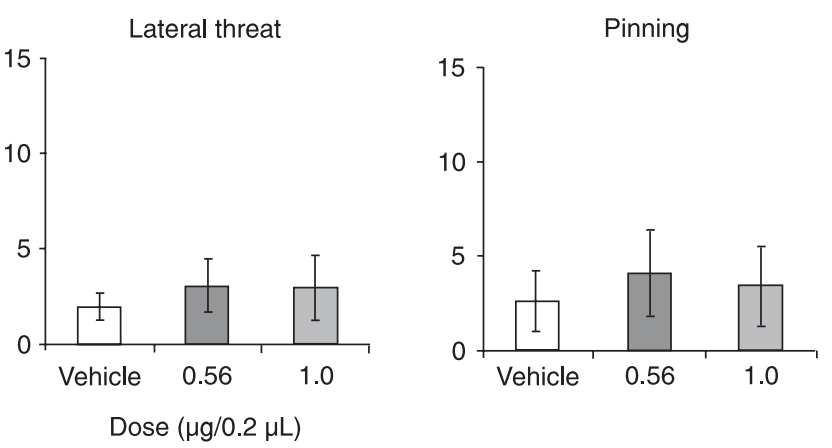

Figure 1. $A$, Effects of $\mathrm{CP}-93,129$, a $5-\mathrm{HT}_{1 \mathrm{~B}}$ receptor agonist, microinjected into the ventro-orbitofrontal prefrontal cortex (VO PFC) at the dose of $1.0 \mu \mathrm{g} /$ $0.2 \mu \mathrm{L}(\mathrm{N}=9)$ relative to the saline group. ${ }^{*} \mathrm{P}<0.05$ compared to control (Student $t$-test). $B$, Effects of CP-94,253, a 5-HT $1 \mathrm{~B}$ receptor agonist, and vehicle $(\mathrm{N}=8)$ microinjected into the VO PFC at the dose of $0.56 \mu \mathrm{g} / 0.2 \mu \mathrm{L}(\mathrm{N}=8)$ and $1.0 \mu \mathrm{g} / 0.2 \mu \mathrm{L}(\mathrm{N}=8$; one-way ANOVA). Data are reported as the mean frequency \pm SEM of lateral attack, lateral threat and pinning during a 10-min test against an intruder male by lactating female rats; $C$, Coronal slice from the female brain showing the site of microinjection into the VO PFC. The arrow indicates the trajectory of the cannula. 
temic injections of this compound are also very effective in decreasing species-typical aggressive behavior of male mice in the resident-intruder model and in alcoholheightened aggressive behavior in mice (2) as well as in suppressing the motivation to fight in male mice (13). CP-93,129 and CP94,253 are highly selective agonists for the $5-\mathrm{HT}_{1 \mathrm{~B}}$ receptor subtype.

CP-93,129 exhibits much higher binding affinities for the $5-\mathrm{HT}_{1 \mathrm{~B}}$ receptor than for the $5-\mathrm{HT}_{1 \mathrm{~A}}$ receptor relative to the 5-propoxy compound CP-94,253 (185-fold higher selectivity for CP-93,129 vs 45- to 60-fold higher selectivity for CP-94,253 (7). CP93,129 is the most selective ligand for the 5$\mathrm{HT}_{1 \mathrm{~B}}$ receptor, but it does not penetrate the blood-brain barrier readily (7). Another aspect to be considered is that female rats were used in the present study. Most of the previous studies with $5-\mathrm{HT}_{1 \mathrm{~B}}$ receptor manipulations used male rodents to test aggressiveness. The female rats studied here were tested on the 9th postpartum day in both experiments with the $5-\mathrm{HT}_{1 \mathrm{~B}}$ receptor agonists, ruling out any endocrine factor as being responsible for the differential effects of the two compounds.

In the current experiments, microinjections of CP-93,129 were very effective, and it is likely that these specific anti-aggressive effects are mediated by the $5-\mathrm{HT}_{1 \mathrm{~B}}$ receptors, although future experiments using antagonists will be needed to confirm this mechanism. Moreover, CP-94,253 is a propoxy derivative of CP-93,129 and consequently a less polar compound, which is able to diffuse more readily throughout the microinjected area than CP-93,129. It may be possible that a higher dose of CP-94,253 have been shown to be effective. The prefrontal cortex contains a considerable number of 5 $\mathrm{HT}_{1 \mathrm{~B}}$ receptors (16) and is one of the most important sites for the anti-aggressive effects of the $5-\mathrm{HT}_{1 \mathrm{~B}}$ receptor agonists $(12,13)$. It is important to note that only the offensive components of the female aggressive behavior such as lateral sideways threat, aggressive posture and pinning the intruder were affected by the $5-\mathrm{HT}_{1 \mathrm{~B}}$ receptor agonist, $\mathrm{CP}$ 93,129 , while the defensive behaviors involved in maternal aggression were not affected. It can be hypothesized that the VO PFC is an area that probably stimulates offensive rather than defensive components of behavior in female rats. CP-93,129 reduces lateral attack, which can be characterized as an offensive element of aggression due to its similarity to male territorial behavior. On the other hand, the frontal attack (jump attack) seems to be an element of defensiveness or fear in the reaction of a female to an intruder. CP-93,129 had no effect on this latter type of behavior.

Confirming previous results obtained with other models of aggression, sex and species, the $5-\mathrm{HT}_{1 \mathrm{~B}}$ receptors in the $\mathrm{VO} \mathrm{PFC}$ have effects on the aggressive behavior of female rats. CP-93,129 decreased maternal aggression and CP-94,253 had no behavioral effect on postpartum aggression in Wistar rats, in contrast to its reduction of aggressive behavior in males.

\section{Acknowledgments}

The authors would like to thank Dirson João Stein, Caroline Persch Royer, Quelin Benini, and João Francisco Silveira for technical support. 


\section{References}

1. Olivier B, van Oorschot R. 5-HT1B receptors and aggression: a review. Eur J Pharmacol 2005; 526: 207-217.

2. Fish EW, Faccidomo S, Miczek KA. Aggression heightened by alcohol or social instigation in mice: reduction by the $5-\mathrm{HT}(1 \mathrm{~B})$ receptor agonist CP-94,253. Psychopharmacology 1999; 146: 391399.

3. De Almeida RMM, Miczek KA. Aggression escalated by social instigation or by discontinuation of reinforcement ("frustration") in mice: inhibition by anpirtoline: a 5-HT1B receptor agonist. Neuropsychopharmacology 2002; 27: 171-181.

4. Saudou F, Amara DA, Dierich A, LeMeur M, Ramboz S, Segu L, et al. Enhanced aggressive behavior in mice lacking $5-\mathrm{HT} 1 \mathrm{~B}$ receptor. Science 1994; 265: 1875-1878.

5. Bouwknecht JA, Hijzen TH, van der Gugten J, Maes RA, Hen R, Olivier B. Absence of $5-\mathrm{HT}(1 \mathrm{~B})$ receptors is associated with impaired impulse control in male 5-HT(1B) knockout mice. Biol Psychiatry 2001; 49: 557-568.

6. Millan MJ, Newman-Tancredi A, Lochon S, Touzard M, Aubry S, Audinot V. Specific labelling of serotonin $5-\mathrm{HT}(1 \mathrm{~B})$ receptors in rat frontal cortex with the novel phenylpiperazine derivative, $[3 \mathrm{H}] \mathrm{GR}$ 125,743. A pharmacological characterization. Pharmacol Biochem Behav 2002; 71: 589-598.

7. Koe BK, Nielsen JA, Macor JE, Heym J. Biochemical and behavioral studies of the $5-\mathrm{HT}_{1 \mathrm{~B}}$ receptor agonist, CP-94,253. Drug Dev Res 1992; 26: 241-250.

8. Hasegawa S, Watanabe A, Nishi K, Nguyen KQ, Diksic M. Selective 5-HT1B receptor agonist reduces serotonin synthesis following acute, and not chronic, drug administration: results of an autoradiographic study. Neurochem Int 2005; 46: 261-272.

9. Bruinvels AT, Palacios JM, Hoyer D. Autoradiographic characterisation and localisation of 5-HT1D compared to 5-HT1B binding sites in rat brain. Naunyn Schmiedebergs Arch Pharmacol 1993; 347: 569582.

10. Sari Y, Miquel MC, Brisorgueil MJ, Ruiz G, Doucet E, Hamon M, et al. Cellular and subcellular localization of 5-hydroxytryptamine1B receptors in the rat central nervous system: immunocytochemical, autoradiographic and lesion studies. Neuroscience 1999; 88: 899915.

11. Varnas K, Hall H, Bonaventure P, Sedvall G. Autoradiographic mapping of 5-HT(1B) and 5-HT(1D) receptors in the post mortem human brain using [(3)H]GR 125743. Brain Res 2001; 915: 47-57.

12. De Almeida RM, Rosa MM, Santos DM, Saft DM, Benini Q, Miczek KA. 5-HT(1B) receptors, ventral orbitofrontal cortex, and aggressive behavior in mice. Psychopharmacology 2006; 185: 441-450.

13. Bannai M, Fish EW, Faccidomo SP, Miczek KA. Anti-aggressive effects of agonists at the $5-\mathrm{HT}_{1 \mathrm{~B}}$ receptors in the dorsal raphe nuclei in mice. Psychopharmacology 2007 (in press).

14. Blair RJ. Neurocognitive models of aggression, the antisocial personality disorders, and psychopathy. J Neurol Neurosurg Psychiatry 2001; 71: 727-731.

15. Chudasama Y, Robbins TW. Dissociable contributions of the orbitofrontal and infralimbic cortex to Pavlovian autoshaping and discrimination reversal learning: further evidence for the functional heterogeneity of the rodent frontal cortex. $J$ Neurosci 2003; 23: 8771-8780.

16. Kheramin S, Body S, Herrera FM, Bradshaw CM, Szabadi E, Deakin $\mathrm{JF}$, et al. The effect of orbital prefrontal cortex lesions on performance on a progressive ratio schedule: implications for models of inter-temporal choice. Behav Brain Res 2005; 156: 145-152.

17. Potegal M, Tenbrink L. The behavior of attack-primed and attacksatiated female golden hamsters (Mesocricetus auratus). J Comp Psychol 1984; 98: 66-75.

18. Potegal M. Attack priming and satiation in female golden hamsters: tests of some alternatives to the aggression arousal interpretation. Aggressive Behav 1991; 17: 327-336.

19. Lagerspetz K, Hautojarvi S. The effect of prior aggressive or sexual arousal on subsequent aggressive or sexual reactions in male mice. Scand J Psychol 1967; 8: 1-6. 